\title{
怒りの維持過程——認知および行動の媒介的役割——
}

\author{
遠藤 寛子 ${ }^{1,2}$ 仙台白百合女子大学 湯川 進太郎 筑波大学
}

\section{The mediating roles of cognition and behavior in the process of maintaining anger}

\author{
Hiroko Endo (Sendai Shirayuri Women's College) and Shintaro Yukawa (University of Tsukuba)
}

\begin{abstract}
Relationships were investigated between the sense of unintegration of thoughts, recurrent thinking, and avoidance behavior, which are considered to be factors in maintaining anger. Undergraduate students $(N=$ 990) were asked to write about anger episodes that they had experienced a week or more ago. Then, they completed a questionnaire assessing their sense of unintegration of thoughts at the present time and just after the episode, their present recurrent thinking, their avoidance behavior after the episode, and their present degree of anger. The results of covariance structure analysis indicated that the sense of unintegration of thoughts just after the episode maintained anger through recurrent thinking. Recurrent thinking also intensified their present sense of unintegration of thoughts, which directly maintained anger. Moreover, the sense of unintegration of thoughts just after the episode led to an increase in avoidance behavior, which was related to recurrent thinking.
\end{abstract}

Key words: anger, sense of unintegration of thoughts, recurrent thinking, avoidance behavior.

The Japanese Journal of Psychology

2012, Vol. 82, No. 6, pp. 505-513

怒りは，日常的に経験しやすい感情であるものの， 一般的には時間とともに鎮静される（日比野・湯川, 2004)。しかし，怒りを感じた状況から離れ，一時的 に怒りが収まったとしても，その後よみがえり，悩ま せられることも多いといわれる（手塚・敦賀・村瀬・ 鈴木, 2007)。こうして怒りが維持される場合, 攻撃 的な反応を示しやすくなり, 対人関係の悪化を招く可 能性がある（Zilliman, 1971）。またそれだけに留まら ず, しばしば心身に負荷をかけ，健康への害にもつな がる（渡辺・小玉，2001）。このように，怒りにとら われ続けると, 対人交流や健康上の問題において様々 な形で悪影響を及ぼすことが推測される。したがっ て, 怒りを維持させないための方法を見出すために も，まずは，怒りの鎮静を阻害している過程を検討す ることが最優先課題になると考えられる。本研究で は，一度経験した怒りが，時間とともに減衰せずに， その後も残存し続ける状態を“怒りの維持”と呼ぶ。

Correspondence concerning this article should be sent to: Hiroko Endo, Institute of Psychology, University of Tsukuba, Tennodai, Tsukuba 305-8572, Japan (e-mail: fehiroko@human.tsukuba.ac. jp)

現所属 : 筑波大学

2 東北学院大学 堀毛 裕子先生, 大江 篤志先生, 加藤 健二 先生には, 貴重なご示唆を頂きました。媣く感謝致します。
反復思考と怒りの維持 近年, 怒りが長引く背景に ついて, 怒りを感じた出来事に対する思考形式（荒 井・湯川, 2006) やストレスフルな出来事に関する記 憶や思考といった, 認知過程に注目することへの必要 性が指摘されている (Davidson, Shwartz, Sheffield, Mccord, Lepore, \& Gerin, 2002)。特に, Davidson et al.（2002）は，ストレスフルな出来事の後も, 再び 怒りが喚起される理由として, 過去の出来事に関わる 思考が繰り返し意識上に浮かぶという侵入思考の存在 をあげている。また, Speckens, Ehlers, Hackmann, Ruths, \& Clark（2007）は, 侵入思考が生起すること で精神的苦痛や怒りが増大することを明らかにしてい る。さらに, 侵入思考と同様に, 反すうも怒りを維持 させる要因であることが示されている。例えば, 最近 の怒りを感じた出来事について想起する際に, 感情面 や状況場面について反すうすると, 怒りが増大したこ とが報告されている（Ray, Wilhelm, \& Gross, 2008）。 また, 過去の出来事を何度も繰り返し思い出すという 反すうの生起が怒りの持続をもたらし，ひいては特性 的な怒り傾向に結びつくとの知見もある（荒井・湯 川, 2006)。

したがって, 怒りを感じた出来事の後にも, その状 況にまつわる怒りが頻繁に想起される背後には，侵入 思考拉よび反すうが強く関連しているといえる。すな 
わち, 怒りは, 出来事中にのみ生じるのではなく, 侵 入思考や反すうによって, 出来事後も再体験されるこ とを意味する。また，その状態が一定期間続くことで いつまでも怒りから解放されないことが示唆される。

侵入思考と反すうは，どちらも制御は容易でなく， 反復的に生起するという点でほぼ類似した概念である と考えられる。また，Martin＆Tesser（1996）も，意 志とは関係なく繰り返し生起される思考として共通性 を認めている。そこで本研究では, 侵入思考と反すう を怒りの反復思考という点で類似の概念とし, 両者を 反復思考の下位要素として扱う。

思考の未統合感と反復思考 侵入思考はストレスフ ルな出来事に関わる認知の統合が不完全な場合に促進 される，という指摘がある（Lepore, Ragan, \& Jones, 2000; Lepore, 2001; Davidson et al., 2002)。すなわち, あるストレスフルな出来事を知覚した場合, 自己や世 界観に関する心的な概念枠組みとその出来事に付随す る情報とが不一致な状態になると, 侵入思考が生起す る過程が推測されている（Horowitz, 1986; Lepore et al., 2000; Lepore, 2001)。この議論に加えて, 侵入思 考は, ストレスフルな出来事を再解釈し, 脅威や混乱 を伴わない形で既存の概念枠組みへと統合することで 弱まるとも仮定されている。言い換えれば，出来事を 受容し, 感情的あるいは理論的に解決した状態が認知 的統合に相当するといえる。したがって, 過去の出来 事に関する勈威, 受容, 理解の程度が侵入思考の増減 を左右する指標となりうる。

また，人は本来，未解決な事柄に関して意味を見出 そうとする欲求を備えている。このため，ある事柄へ の解決策が見つからず，意図した方向性と不一致であ ると知覚した場合には，反すうが生じる（Martin \& Tesser, 1996)。この視座は, Zeigarnik 効果に基づい ている（Zeigarnik, 1938)。すなわち，トラウマやス トレスフルな出来事に遭遇した時に反すうが起こるの は, 出来事が状況的に自身の意眓する方向へと完了さ れなかったことによる (Pennebaker, 1997 余語監訳 2000)。また，最近では，未完了事象に対して主観的 な注目が高まった時に反すうの増加が顕著になるとの 見解もある（木村, 2004)。このように, 出来事が個 人の意図する方向へ首尾よくたどり着いていないとい う未完了感が強いほど, 反すうも増強する可能性が考 えられる。

そこで本研究では, 侵入思考・反すうの生起を左右 する要因として，認知的統合の欠如（Horowitz, 1986; Lepore et al., 2000; Lepore, 2001; Davidson et al., 2002)，および未完了感 (Martin \& Tesser, 1996; 木 村，2004）に着目し，これらをまとめて“思考の未統 合感”と命名する。具体的には, “過去の出来事に対 して目指すべき方向に解決されていない, 受容できな い，脅かされると感じること”と定義する。この“思
考の未統合感”が侵入思考や反すうなどの反復思考を もたらし，それによって怒りが維持される過程が想定 される。

ところで, 反復思考は逆に, 思考の未統合感の強化 につながることも考えられる。侵入思考や反すうなど の反復思考は，意志とは無関係に意識に浮かび，目的 そのものや過去の感情に注意が向かうため（Martin \& Tesser, 1989), 思考が深化しないと考えられる。ま た，反すうと近似の概念と考えられている “心配”

は, 解決に向けての意図が動機づけられているもの の, その一方で, 問題が解決されていないという未解 決感を強め, さらなる心配を増幅させると報告されて いる（杉浦，1999）。これらの知見を考慮すると，思 考の未統合感が反復思考に影響を及ぼし, 怒りを維持 させるという過程以外に, 反復思考をし続けること が, 思考の未統合感を維持・強化するという過程も想 定される。

さらに, 思考の未統合感それ自体も, 怒りの維持に 直接影響を及ぼすことが考えられる。遠藤（2009）

は, 怒りを感じた過去の出来事について, 3 日間連続 して筆記を求めた結果，筆記するにしたがい，洞察や 理解を表す認知語が多くなるほど，その出来事にまつ わる理解の程度が促され，怒りが鎮静したことを明ら かにしている。つまり, 出来事に対して理解を深める こと自体も，怒りの維持を緩和させることにつながる といえる。逆に考えれば, 出来事に対する思考の未統 合感は, それ自体が直接的に怒りの維持を促している 可能性もある。

ここまでの議論をまとめると, 怒りを感じた出来事 の直後に思考の未統合感が強いほど, しばらくは反復 思考が生起し, その結果, 怒りが維持されると予測さ れる。一方，そうした反復思考もまた思考の未統合感 を維持・強化し, その未統合感が怒りの維持をもたら すと予測される。

回避行動と怒りの維持 怒りを感じた出来事の後, 認知的には反復思考が生じる一方で, 行動的には回避 行動が生じる可能性が高い。すなわち人は, 予想外で 受容し難い出来事に遭遇すると, 他のことに没頭する ことで注意を逸らし，そこから回避しょうとする傾向 にある(Pennebaker, 1997 余語監訳 2000)。このよ うな回避行動には, 趣味にいそしむといった気晴らし なども含まれる。こうした気晴らしは，混沌とした状 態から, 一時的に離れられるという点においては有効 である（村山・及川，2005）。しかし，それは短期的 な効果に限られる可能性が高い。なぜなら, 出来事に 対して回避的に対処するほど特性怒りが高いという報 告（湯川・日比野, 2003）や, 思考から離れる戦略と して別の対象に注意を向ける行為は逆説的効果が促さ れ, 思考がより増加されるという報告 (Wegner, Schneider, Carter, \& White, 1987）にもあるように，思 
Table 1

思考の未統合感（出来事直後掞よび最近）尺度の主成分分析結果

\begin{tabular}{|c|c|c|c|c|}
\hline & \multicolumn{2}{|c|}{ 直後 $(\alpha=.78)$} & \multicolumn{2}{|c|}{ 最近 $(\alpha=.85)$} \\
\hline & 平均 $(S D)$ & 負荷量 & 平均 $(S D)$ & 負荷量 \\
\hline この出来事に対して未だ整理がついていない & $2.43(0.96)$ & .84 & $2.46(0.98)$ & .87 \\
\hline この出来事に対して自分なりの決着がついていない & $2.58(1.02)$ & .80 & $1.94(0.98)$ & .84 \\
\hline この出来事に対して考えをまとめることができない & $2.23(1.07)$ & .79 & $1.78(0.99)$ & .80 \\
\hline この出来事は, 私をおびやかしている & $2.19(1.07)$ & .61 & $2.46(1.01)$ & .74 \\
\hline \multirow[t]{2}{*}{ この出来事を受け入れられない } & $2.50(0.94)$ & .58 & $1.76(0.88)$ & .72 \\
\hline & & 2.68 & & 3.16 \\
\hline
\end{tabular}

考を回避する行為は, 結果的に反復思考の増加につな がる場合があるからである。したがって，回避行動は 怒りの制御を考える上で，中長期的には有害になる可 能性がある（日比野・湯川, 2004）。

これらを踏まえると，次のような過程が導かれる。 すなわち, 出来事に対して受容ができずに脅威を感じ ることで（つまり，思考の未統合感が生じることで), 気晴らしなどの回避行動がもたらされる。そして,こ の回避行動のために反復思考の増大がもたらされ, こ れによって怒りが長引くと予測される。

本研究の目的と仮説モデル 以上の点から, 本研究 では, 怒りの維持過程の仮説モデルとして, 思考の未 統合感が “反復思考”を促し怒りの維持につながると いう流れの中で, 反復思考が思考の未統合感を維持 . 強化する可能性, 思考の未統合感そのものが怒りの維 持につながる可能性を検討する。また，思考の未統合 感が “回避行動”を促し，それが反復思考をもたら し, 怒りの維持につながる可能性を含めて検討する。

\section{方法}

\section{調査対象者と手続き}

調査対象者として，M 県内の 4 大学において, 990 名の回答を得た (男性 255 名, 女性 735 名)。平均年 齢は 20.16 歳 $(S D=1.56)$ であった。

講義時間等を利用して調査対象者に質問紙を配布 し，調査に先立って，書面による同意を得た後に回答 を求めた。なお，その際，気分が悪くなったり，回答 できなくなったりした場合は，いつでも回答を中止す ることができることを伝えた。調查終了後, 調査内容 についての説明を行い, 質問を受け付けた。調査を通 して, 気分の悪化を訴えた調査対象者はいなかった。

\section{質問紙の構成}

はじめに, 1 週間以上前の出来事で，不愉快にさせ られたり，非難されたりなど，ストレスを感じた最も 強い怒りの出来事を一つだけ想起してもらい, 記述を 求めた。このとき, その出来事が起こった時期につい
てできるだけ詳しい回答を求めた。次に，その出来事 について, 以下の質問に沿って回答を求めた。

\section{指 標}

思考の未統合感 Horowitz (1986), Lepore et al. （2000）および Martin \& Tesser（1996）を参考に定義 した内容に基づき，質問項目を 7 項目作成した。その 際，思考の未統合感については，時間的な流れを考慮 し, 出来事直後のもの（直後の思考の未統合感）と最 近のもの（最近の思考の未統合感）とに区別し，それ ぞれについて回答を求めた。具体的な項目は, Table 1 に示した。各項目について, 1 (全くあてはまらない) から4（とてもよくあてはまる）の４件法で尋ねた。

回避行動 本研究では, 湯川・日比野 (2003) より 得られた知見を参考にし, 気晴らしを回避行動とし た。怒りの出来事から現在までにとった行動について 尋ねた。具体的な項目は, Table 2 に示した。各項目 について，1（全くしなかった）から4（たいへんよ くした）の 4 件法で尋ねた。

反復思考 反復思考に関わる尺度として, 怒りの侵 入思考尺度と怒りの反すう尺度をそれぞれ作成した。 怒りの侵入思考に関しては, 飛鳥井 (1999) の改訂出 来事インパクト尺度の下位尺度である “侵入的想起 再体験”の 8 項目を, また, 怒りの反すうに関して は, 伊藤・上里（2001）のネガティブな反すう尺度の 下位尺度である“ネガティブな反すう傾向”７項目を それぞれ参考にして, 怒りを感じた出来事に合致する ように作成した。

怒りの侵入思考尺度は，怒りを感じた出来事に対し て, 最近どのような状態になるかについて，1（全く ない）から 5 (非常にある) の 5 件法で尋ねた。怒り の反すう尺度は, 怒りを感じた出来事に関して, 1 (あてはまらない) から6（あてはまる）の6 件法で 尋ねた。具体的な質問項目は, Table 2 に示した。

怒りの維持 記述した怒りの出来事について, 今で も怒りを感じるかという問いに対して，1（全くあて はまらない) から4（とてもよくあてはまる）の 4 件 法で尋ねた。 
Table 2

回避行動・怒りの侵入思考尺度・怒りの反すう尺度の主成分分析結果

\begin{tabular}{|c|c|c|}
\hline 回避行動（ $\alpha=.88 ）$ & 平均 $(S D)$ & 負荷量 \\
\hline 別な事をして気分転換を図る & $2.34(1.11)$ & .91 \\
\hline 本を読んだり，テレビをみたりするなどして他の事に没頭する & $2.32(1.14)$ & .90 \\
\hline \multirow[t]{2}{*}{ 気晴らしになることを探す } & $2.27(1.12)$ & .89 \\
\hline & 固有值 & 2.42 \\
\hline 怒りの侵入思考 $(\alpha=.91)$ & 平均 $(S D)$ & 負荷量 \\
\hline 怒りの出来事について, 感情が強くこみあげてくることがある & $2.32(1.25)$ & .88 \\
\hline 考えるつもりはないのに，怒りの出来事を考えてしまうことがある & $1.77(1.11)$ & .87 \\
\hline 別のことをしていても, 怒りの出来事が頭から離れないことがある & $1.95(1.20)$ & .86 \\
\hline 怒りの出来事の場面が, いきなり頭にうかんでくることがある & $1.94(1.18)$ & .85 \\
\hline $\begin{array}{l}\text { どんなきっかけでも, 怒りの出来事を思い出すと, そのときの気持ちがぶりかえしてくることが } \\
\text { ある }\end{array}$ & $1.56(1.02)$ & .79 \\
\hline $\begin{array}{l}\text { 気がつくと，まるで怒りの出来事にもどってしまったかのように，ふるまったり感じたりするこ } \\
\text { とがある }\end{array}$ & $1.96(1.24)$ & .77 \\
\hline $\begin{array}{l}\text { 怒りの出来事を思い出すと，身体が反応して，汗ばんだり，息苦しくなったり，むかむかした } \\
\text { り，どきどきすることがある }\end{array}$ & $1.56(1.08)$ & .75 \\
\hline \multirow[t]{2}{*}{ 怒りの出来事についての夢を見ることがある } & $1.31(0.83)$ & .49 \\
\hline & 固有值 & 5.01 \\
\hline 怒りの反すう（ $(\alpha=.85 ）$ & 平均 $(S D)$ & 負荷量 \\
\hline 怒りの出来事を 30 分以上途切れなく考え続ける & $1.82(1.24)$ & .80 \\
\hline 何日もの間, 怒りの出来事を考えるのに没頭することがある & $2.44(1.54)$ & .80 \\
\hline しばしば，怒りの出来事ばかりを途切れなく考え続けることがある & $1.98(1.35)$ & .77 \\
\hline 一度怒りの出来事を考え始めると，そればかりを途切れなく考え続けてしまう & $2.36(1.49)$ & .77 \\
\hline 一日中ずっと, 怒りの出来事ばかりを考え続ける & $1.46(1.00)$ & .72 \\
\hline \multirow[t]{2}{*}{ 同じ怒りの出来事を何度も繰り返して考えている } & $2.16(1.52)$ & .71 \\
\hline & 固有值 & 3.50 \\
\hline
\end{tabular}

\section{結果}

\section{尺度の基本的検討}

思考の未統合感 直後の思考の未統合感尺度と最近 の思考の未統合感尺度それぞれについて主成分分析を 行った結果, 両尺度ともに同一の 2 項目の負荷量が低 かったため, これらを除外し，残りの 5 項目による主 成分分析を再度行った。その結果, 直後の思考の未統 合感尺度と最近の思考の未統合感尺度それぞれの第 1 主成分の寄与率は， $53.68 \% ， 63.18 \%$ であり，共に 1 因子構造であることが確認された 3 。また，直後の思

3 思考の未統合感について, 時期 (直後, 最近) および性に よって平均得点の差に違いがあるかを確認するため, 思考の未 統合感 (直後, 最近) と性の二要因混合計画に基づく分散分析 を行った。その結果, 時期の主効果が有意であり $(F(1,988)=$ $379.83, p<.001)$, 思考の未統合感は, 直後よりも最近の方が有 意に低いことが示された。しかし, 時期と性との交互作用は有 意ではなかった $(F(1,988)=.53, n s)$ 。
考の未統合感尺度の $\alpha$ 係数は.78, 最近の思考の未統 合感尺度の $\alpha$ 係数は.85 であり, 内的整合性は十分に 高かった。

回避行動 3 項目に対して主成分分析を行った結 果, 第 1 主成分の寄与率は $80.81 \%$ であり, 1 因子構 造であることが確認された。 $\alpha$ 係数は.88であり, 内 的整合性は十分に高かった。

反復思考 怒りの侵入思考尺度を構成する 8 項目に ついて主成分分析を行った結果（Table 2)，第 1 主成 分の寄与率は $75.29 \%$ であり, 1 因子構造であること が確認された。また，尺度の $\alpha$ 係数は.91であり，内 的整合性は十分に高かった。怒りの反すう尺度を構成 する 7 項目について主成分分析を行った結果, 1 項目 のみ負荷量が低かったため, これを除外し, 残りの 6 項目による主成分分析を再度行った。その結果，第 1 主成分の寄与率は $58.31 \%$ であ， 1 因子構造である ことが確認された。また，尺度の $\alpha$ 係数は.85であ り, 内的整合性は十分高かった。 
Table 3

怒りの維持と想起した出来事の時期に関するクロス集計結果

\begin{tabular}{lccccc}
\hline & $\begin{array}{c}\text { 1 週間以上 } \\
\text { 2 週間未満 }\end{array}$ & $\begin{array}{c}\text { 2 週間以上 } \\
\text { 1 月未満 }\end{array}$ & $\begin{array}{c}\text { 1 } \\
\text { 3力月未上満 }\end{array}$ & 3力月以上 & 合計 \\
\cline { 1 - 4 } 怒り維持群 & 227 & 137 & 62 & 85 & 511 \\
& $(23.7)$ & $(14.3)$ & $(6.5)$ & $(8.9)$ & $(53.3)$ \\
怒り非維持群 & 218 & 106 & 44 & 79 & 447 \\
& $(22.8)$ & $(11.1)$ & $(4.6)$ & $(8.2)$ & $(46.7)$ \\
\hline 合計 & 445 & 243 & 106 & 164 & 958 \\
& $(46.5)$ & $(25.4)$ & $(11.1)$ & $(17.1)$ & $(100.0)$ \\
\hline
\end{tabular}

a) 上段は人数, 下段（）内は\%を示す。

Table 4

思考の未統合感 · 回避行動 - 怒りの反復思考 - 怒りの維持の相関分析結果

\begin{tabular}{|c|c|c|c|c|c|c|c|c|}
\hline & 男性 $(n=255)$ & 女性 $(n=735)$ & & & & & & \\
\hline & 平均 $(S D)$ & 平均 $(S D)$ & 1 & 2 & 3 & 4 & 5 & 6 \\
\hline \multicolumn{9}{|l|}{ 思考の未統合感 } \\
\hline 1 出来事直後 & $2.23(0.78)$ & $1.86(0.75)$ & - & $.75^{* * *}$ & $.23 * * *$ & $.52 * * *$ & $.43^{* * *}$ & $.46^{* * *}$ \\
\hline 2 最近 & $1.85(0.84)$ & $2.27(0.74)$ & $.72 * * *$ & - & $.27 * * *$ & $.61^{* * *}$ & $.54 * * *$ & $.52 * * *$ \\
\hline 3 回避行動 & $2.26(1.05)$ & $2.33(1.00)$ & .07 & $.18^{* *}$ & - & $.29 * * *$ & $.27 * * *$ & $.24 * * *$ \\
\hline \multicolumn{9}{|l|}{ 怒りの反復思考 } \\
\hline 4 怒りの侵入思考 & $1.80(0.95)$ & $1.80(0.86)$ & $.39 * * *$ & $.62 * * *$ & $.29 * * *$ & - & $.72 * * *$ & $.50 * * *$ \\
\hline 5 怒りの反すう思考 & $2.01(1.04)$ & $2.05(1.04)$ & $.37 * * *$ & $.53 * * *$ & $.32 * * *$ & $.74 * * *$ & - & $.41 * * *$ \\
\hline 6 怒りの維持 & $2.22(1.11)$ & $2.40(1.07)$ & $.43 * * *$ & $.59 * * *$ & $.18^{* *}$ & $.47 * * *$ & $.33^{* * *}$ & - \\
\hline
\end{tabular}

注）対角線より右上が女性の，左下が男性の相関係数を表す。 ${ }^{* * *} p<.001,{ }^{* *} p<.01$

\section{基礎的データの検討}

怒りの維持と想起した出来事の時期 時期に関して 無記入であった 32 名を除き, 怒りを感じた出来事に 対して, 最近も怒りを維持している群と維持していな い群に分け，出来事の時期ごとに割合を算出した。そ の結果を Table 3 に示す。 $\chi^{2}$ 検定を行った結果，群間 で時期の割合に有意差はなかった $\left(\chi^{2}(3)=3.15, n s\right)$ 。 すなわち, 現時点で怒りを維持しているか否かにかか わらず，想起した出来事の時期についての人数比に違 いは見られなかった。

変数間の関連性 各変数間の関連性を確認するため に，また，性別によって関連性に違いがあるかを明ら かにするために相関分析を行った。結果を Table 4 に 示す。男性において, 思考の未統合感 (出来事直後) と回避行動の相関のみ有意ではなかったものの, この 他はすべて同様の相関関係が示され, 顕著な性差は見 出されなかった。

\section{仮説モデルの検討}

本研究では, 怒りの維持過程として, （直後の）思 考の未統合感が “反復思考”を促し怒りの維持につな
がるという流れの中で, 反復思考が（最近の）思考の 未統合感を維持・強化する可能性, （最近の）思考の 未統合感そのものが怒りの維持につながる可能性,さ らに, (直後の) 思考の未統合感が “回避行動”を促 し，それが反復思考をもたらし，怒りの維持につなが る可能性を含めた仮説モデルを想定した4。このモデ ルにしたがって，まず，共分散構造分析を行った5。 その際, 母数の推定方法には最尤法を用いた。分析の 結果, 適合度は, $\chi^{2}(96)=318.43(p<.001), \mathrm{GFI}=.96$, $\mathrm{AGFI}=.94, \mathrm{CFI}=.97, \mathrm{RMSEA}=.05$ であり, 十分に

4 思考の未統合感, 反復思考 (侵入思考, 反すう), 回避行 動, 怒りの維持に関して性差の検討を行った結果，怒りの維持 のみに若干ながら有意差が認められた $(t(988)=2.407, p<.05)$ 。 すなわち, 女性 $(M=2.40, S D=1.07)$ は男性 $(M=2.22, S D=$ 1.11）よりも怒りを維持しやすいことが示された。ただし，その 差はごくわずかなこと, 変数間の相関にも顕著な性差は見られ ないこと,さらに先行研究において怒りに性差は見られないこ とから（日比野·湯川, 2003; 大㴊・小倉, 1984), 本研究では, 男女达みで分析を行うこととした。

5 山本・小野寺（1999）に基づき, 分析に用いる尺度の第一 主成分への負荷量が高い項目から順に 3 項目ずつ選定して潜在 変数を構成した。 
Table 5

多母集団同時分析の結果（適合度指標）

\begin{tabular}{lccccccc}
\hline & $\chi^{2}$ 值 & $d f$ & GFI & AGFI & CFI RMSEA & AIC \\
\hline モデル 1 & 749.92 & 384 & .91 & .88 & .96 & .03 & 1069.92 \\
モデル 2 & 789.95 & 420 & .91 & .88 & .96 & .03 & 1037.95 \\
モデル 3 & 809.95 & 438 & .91 & .89 & .96 & .03 & 1021.95 \\
モデル 4 & 810.39 & 441 & .91 & .89 & .96 & .03 & 1016.39 \\
\hline
\end{tabular}

注） $\chi^{2}$ 検定の結果は，いずれのモデルも $p<.001$ であった。

高い適合性を示していた。続いて, 想起した出来事の 時期が怒りの維持過程に影響しているかどうかを確認 するため，時期を 4 群に区分し，上記のモデルについ て多母集団同時分析を行った。具体的には，1 週間以 上 2 週間未満 $(445$ 名), 2 週間以上 1 力月未満 $(243$ 名), 1 月以上 3 力月未満 (106 名), 3力月以上 (164 名）の 4 群を設けた。そして，4群間に等值制約を置 かないものをモデル 1, 測定方程式のパス係数のみに 等值制約を置いたものをモデル 2, 測定方程式および 構造方程式のパス係数に等值制約を置いたものをモデ ル 3, 測定方程式のパス係数, 構造方程式のパス係 数, 共分散に等值制約を置いたものをモデル 4 とし て，モデルごとに適合度指標を算出し，モデル間の比 較を行った（Table 5 参照）。Table 5 で示されたよう に，モデル 4 において AICの值が最も低く，いずれ の適合度指標でも十分な值が得られたため, このモデ ルを採択した。したがって, これらの結果から 4 群間 で測定方程式および構造方程式のパス係数, 共分散に 大きな差はなく，想起した出来事の時期によって怒り の維持過程に差はないものと判断された。

モデル 4 の結果を Figure 1 に示す。。まず，思考の 未統合感が “反復思考”へと向かうルートについて
は, Figure 1 にあるように, 怒りを感じた出来事直 後の思考の未統合感が, 怒りの反復思考を促進し, 怒 りの維持へと結びついていた。また，反復思考が出来 事に対する最近の思考の未統合感を高め,ひいては怒 りを維持させていた。一方, 怒りを感じた出来事直後 の思考の未統合感は, 最近の思考の未統合感を高め,

これが怒りを維持させていた。

次に，思考の未統合感が “回避行動”をもたらすル ートについては, Figure 1 の通り, 怒りを感じた出 来事の直後に生じた思考の未統合感が回避行動を促し ていた。そして, 回避行動は怒りの反復思考を介して 怒りの維持へ, さらに最近の思考の未統合感を介して 怒りの維持へと結びつくことも示された。なお，回避 行動そのものと, 最近の思考の未統合感や怒りの維持 との間には，直接的なつながりは見られなかった。

\section{考察}

本研究では, 第一に, 基礎的データとして, 怒りの 維持および出来事の時期について確認した。その結 果, 過去の出来事に対して最近も怒りを維持している 人が半数いることが示された。また，その怒りの維持 期間は, 主に 1 週間以上 2 週間未満が顕著であった が，3力月以上維持する場合もあることが明らかとな った。このことから, 日常生活においては, 1 週間程 度で鎮静される怒りが多い中（日比野・湯川，2004）, それ以上に長引く怒りも存在することが確認できたと

6 侵入思考と反すうは，従来，個々に検討されてきたが（飛 鳥井, 1999; 伊藤・上里, 2001), それらを包含して論じる立場 (Martin \& Tesser, 1996）もある。これらの両視点を鑑み, 本研 究では, 尺度上（手続き上）では区別しつつも同一の概念とし て捉えた。

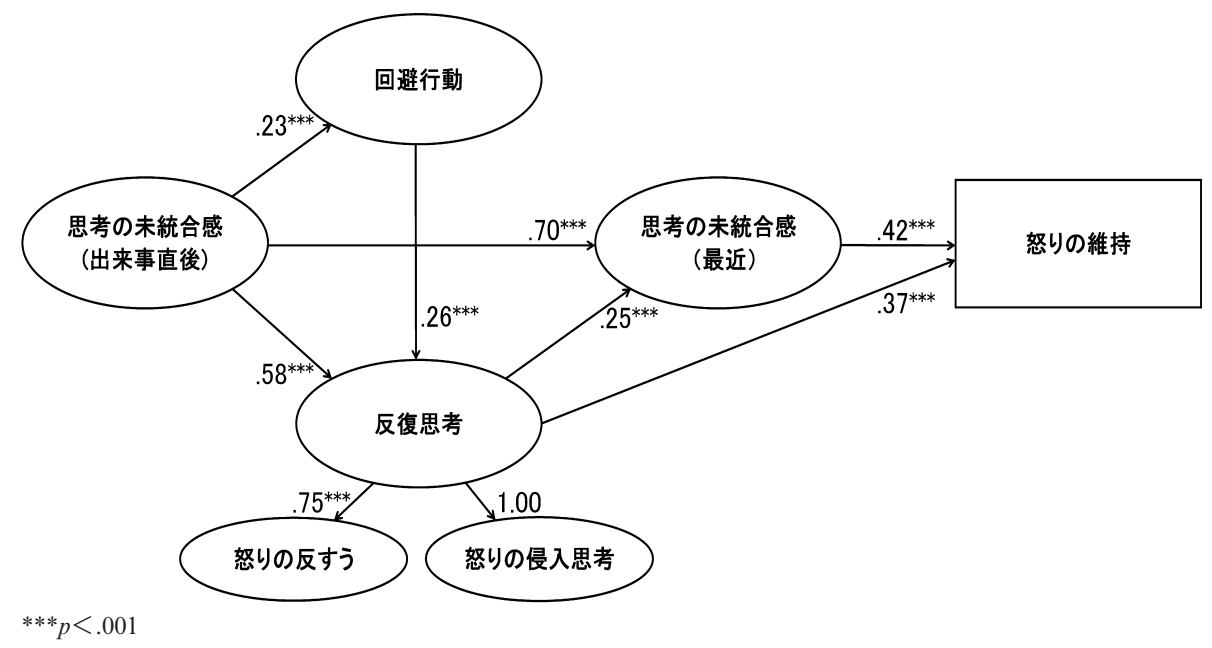

Figure 1. 怒りの維持過程の共分散構造分析結果

注） 観測変数および誤差変数は, 図より省略した。図中の数值は, 非標準化係数を示す。 
いえる。

こうした結果を踏まえ，第二に，本研究では，思考 の未統合感が反復思考をもたらし怒りの維持に結びつ く過程, 反復思考が思考の未統合感を維持・強化し, それが怒りの維持につながる過程，さらには，思考の 未統合感が回避行動を促し反復思考に至る過程につい て仮説モデルを立て, 共分散構造分析を用いて検討し た。その結果, 仮説モデルを支持する結果が得られ た。

本研究における思考の未統合感とは, 怒りを感じた 過去の出来事に関して整理・受容できない状態を表す が, この思考の未統合感が生じることで, 反復思考が 生起し, それによって過去に経験した怒りが維持され ることが見出された。この反復思考の増加はまた, 思 考の未統合感を強化し，これを媒介して怒りの維持へ とつながる過程も示された。反復思考は, 目的そのも のや過去の感情に注意が向かうため（Martin \& Tesser, 1989), 解決を方向づける思考とは異なる。こ のため, 反復思考の増加は, 過去の出来事に関する思 考の未統合感をさらに強めるのだろう。このように, 怒りの維持をもたらしている鍵は, “思考の未統合感” であることが示された。したがって，怒りの維持を軽 減するには，この思考の未統合感を解消させるための 有効な手段を検討していく必要がある。

一方で, 思考の未統合感は, 回避行動を促進しやす いことも確認された。そして, この回避行動は, 予測 通り反復思考へと結びつき, 結果的に怒りの維持へと つながることが明らかとなった。すなわち，思考を回 避しょうとする行為は, 出来事直後には自らを落ち着 かせる効果があっても， 画一的・継続的に活用するこ とでむしろ有害になる可能性がある（日比野・湯川, 2004）。また，思考から離れようと努力するほどかえ ってそれが増幅されるという逆説的効果が生起してい たと解釈できる（Wegner et al., 1987）。加えて，反す うや侵入思考などの反復思考は, 出来事に関する意味 を探求しようとして生起することも議論されている (Horowitz, 1986; Martin \& Tesser, 1989)。ここから, たとえ反復思考を意図的に避けようとしても，意味を 探そう（探したい）とする潜在的志向によって，避け ようとする意図とは逆に，意味探索を一定以上保とう として, かえって反復思考が増加したのかもしれな い。今後は, 回避行動から反復思考に至る過程をより 明らかにしていくために, 反復思考の適応的機能につ いても検討していく必要がある。ただ，いずれにして も，本研究で得られた知見を考慮すれば，怒りの維持 を防ぐために, 中長期的には, 回避行動以外の対処行 動を模索すべきであろう。

第三に, 本研究では, 怒りの維持と想起した出来事 の時期との関連性を確認し, さらに, こうした時期が 怒りの維持過程に影響を及ぼすか否かについても検討
を行った。その結果, 怒りの維持は, 想起した出来事 の時期に依拠しないことが確認された。すなわち, 今 回の調査では, 怒りの出来事として思い出す際には, 出来事が起きた時期とは関係なく, 怒りが未だに伴っ ている場合と怒りの感情価は消失したものの経験の記 憶として印象深く残っている場合とに大きく分かれて いることが示唆された。また, 出来事の時期は怒りの 維持過程に影響を及ぼしていない可能性も示唆され た。すなわち, 今回の調査結果では, 想起した出来事 からの経過時間の長短は, 怒りの維持の程度や維持さ れる過程を左右しない可能性が示された。

ただし，本研究では，怒りの維持過程を検討するに あたり, 過去の出来事に関して振り返りを求めるとい った想起法および自己報告に基づく質問紙調査を実施 しているため, 明確な因果関係までを結論づけること はできない。今回の示唆を確認するためにも, 今後 は, 縦断的な調査方法を用いることが必要である。ま た, 本研究の結果に打いて, 思考の未統合感と回避行 動の相関関係や怒りの維持得点に若干の性差が示され たことを考慮すると, 今後は, 同様の研究を積み重ね る中で性差が見出されるかどうかを慎重に見極めてい く必要がある。さらに, 怒りを感じる際には, 身近な 相手であることや故意と捉えた場合であることも報告 されている（大㴊・小倉 1984; 湯川・日比野，2003）。 このような知見を踏まえると, 怒りの維持過程は, 個 人内で生じる過程のみではなく出来事を構成する様々 な状況要因にも左右される可能性があるだろう。加え て, 個人差 (特性) も怒りの維持過程に影響を及ぼす 要因の一つであると考えられる。例えば, 状況に対す る認知や感情表現のスキルに欠如が見られるアレキシ サイミア傾向を持つ個人は, 感情を適切に制御するこ とが困難なため (Taylor, Bagby, \& Parker, 1997 福西 監訳 1998), 思考の未統合感が強い可能性が考えられ る。このように, 本研究で示した怒りの維持過程に関 しては, 状況要因や個人差要因を含めた更なる詳細な 検討が望まれる。

\section{引用文献}

荒井 崇史・湯川 進太郎（2006）。言語化による怒り の制御 カウンセリング研究, 39, 1-10.

(Arai, T., \& Yukawa, S. (2006). Verbalization for controlling anger. Japanese Journal of Counseling Science, 39, 1-10.)

飛鳥井望 (1999). 外傷後ストレス障害 (PTSD) 臨床精神医学, 増刊号, 171-177.

(Asukai, N. (1999). Posttraumatic stress disorder (PTSD) . Japanese Journal of Clinical Psychiatry, 28 (Supplement), 171-177.)

Davidson, K., Shwartz, A. R., Sheffield, R. S., Mccord, R. S., Lepore, S. J., \& Gerin, W. (2002). Expressive 
writing and blood pressure. In S. J. Lepore \& J. M. Smyth (Eds.), Writing cure: How expressive writing promotes health and emotional well-being. Washington, DC: American Psychological Association. pp. 17-30.

遠藤 寛子 (2009)。怒り経験の筆記が精神的健康に及 ぼす影響 感情心理学研究, 17, 3-11.

(Endo, H. (2009). Effects of writing about anger experiences on mental health. Japanese Journal of Research on Emotions, 17, 3-11.)

日比野 桂・湯川 進太郎 (2004). 怒り経験の鎮静化 過程——感情 · 認知 · 行動の時系列的変化— 心理学研究, 74, 521-530.

(Hibino, K., \& Yukawa, S. (2004). The calming process of anger experience: Time series changes of affects, cognitions, and behaviors. Japanese Journal of Psychology, 74, 521-530.)

Horowitz, M. J. (1986). Stress response syndromes. 2nd ed. New York: Aronson.

伊藤 拓・上里一郎 (2001). ネガティブな反すう尺 度の作成およびうつ状態との関連性の検討 カウ ンセリング研究, 34, 31-42.

(Ito, T., \& Agari, I. (2001). Developmental of the negative rumination scale and its relationship with depression. Japanese Journal Counseling Science, 34, 31-42.)

木村 晴 (2004). 未完結な思考の抑制とその影響 教 育心理学研究, 52, 44-51.

(Kimura, H. (2004). Effects of suppressing thoughts about incomplete events. Japanese Journal of Educational Psychology, 52, 44-51.)

Lepore, S. J. (2001). A social-cognitive processing model of emotional adjustment to cancer. In A. Baum \& B. Andersen (Eds.), Psychosocial interventions for cancer. Washington, DC: American Psychological Association. pp. 99-118.

Lepore, S. J., Ragan, J., \& Jones, S. (2000). Talking facilitates cognitive-emotional processes of adaptation to an acute stressor. Journal of Personality and Social Psychology, 78, 499-508.

Martin, L. L., \& Tesser, A. (1989). Toward a motivational and structural theory of ruminative thoughts. In J. S. Uleman \& J. A. Bargh (Eds.), Unintended thought. New York: Guilford Press. pp. 306-326.

Martin, L. L., \& Tesser, A. (1996). Some ruminative thoughts. In R. S. Wyer, Jr. (Ed.), Advances in social cognition. Vol. 9. Ruminative thoughts. New Jersey: Lawrence Erlbaum Associates, Inc. pp. 147.

村山 航・及川 恵 (2005). 回避的な自己制御方略は 本当に非適応的なのか 教育心理学研究, 53, 273-286.

(Murayama, K., \& Oikawa, M. (2005). Are avoidance storategies always maladapyive? Japanese Journal of Educational Psychology, 53, 273-286.)

大㴊 憲一・小倉 左知男 (1984). 怒りの経験(1)アベリルの質問紙による成人と大学生の調査概況
- 犯罪心理学研究, 22, 15-35.

(Ohbuchi, K., \& Ogura, S. (1984). The expression of anger (1): The Survey for Adults and University Students With Averill's Questionnaire. Japanese Journal of Crime Psychology, 22, 15-35.)

Pennebaker, J. W. (1997). Opening up: The healing power of expressing emotions. New York: Guilford Press.

(ペネベーカー J. W. 余語 真夫（監訳）（2000）. オープニングアップ——秘密の告白と心身の健康 一一北大路書房)

Ray, R. D., Wilhelm, F. H., \& Gross, J. J. (2008). All in the mind's eye? Anger rumination and reappraisal. Journal of Personality and Social Psychology, 94, 133-145.

Speckens, A. E. M., Ehlers, A., Hackmann, A., Ruths, F. A., \& Clark, D. M. (2007). Intrusive memories and rumination in patients with posttraumatic stress disorder. Memory, 15, 249-257.

杉浦 義典 (1999). 心配の問題解決志向性と制御困難 性の関連 教育心理学研究, 47, 191-198.

(Sugiura, Y. (1999). Worry: Problem-solving orientation and uncontrollability. Japanese Journal of Educational Psychology, 47, 191-198.)

Taylor, G. J., Bagby, R. M., \& Parker, J. D. A. (1997). Disorders of affect regulation: Alexithymia in medical and psychiatric illness. New York: Cambridge University Press.

(テイラー, G.J.・バグビー, R. M.・パーカー, J. D. A. 福西勇夫（監訳）（1998）。アレキシサ イミア一一感情制御の障害と精神・身体疾患— 星和書店）

手塚 洋介・敦賀 麻理子・村瀬 裕子・鈴木 直人 (2007). 認知的評価がネガティブ感情体験と心臓血管反応 の持続に及ぼす影響 心理学研究, 78, 42-50.

(Tezuka, Y., Tsuruga, M., Murase, Y., \& Suzuki, N. (2007). The influence of cognitive appraisal on the duration of negative emotional experience and cardiovascular response. Japanese Journal of Psychology, 78, 42-50.)

渡辺 俊太郎 - 小玉 正博 (2001). 怒り感情の喚起 · 持続傾向の測定——新しい怒り尺度の作成と信頼 性・妥当性の検討——健康心理学研究, 14, 32-39.

(Watanabe, S., \& Kodama, M. (2001). Assessment of anger arousal and anger lengthiness. Japanese Journal of Health Psychology, 14, 32-39.)

Wegner, D. M., Schneider, D. J., Carter, S. R., \& White, T. L. (1987). Paradoxical effects of thought suppression. Journal of Personality and Social Psychology, 53, 5-13.

山本嘉一郎・小野寺孝義 (1999)。Amosによる共 分散構造分析と解析事例 ナカニシヤ出版 (Yamamoto, I., \& Onodera, T.)

湯川進太郎・日比野 桂 (2003). 怒り経験とその鎮 静化過程 心理学研究, 74, 428-436.

(Yukawa, S., \& Hibino, K. (2003). Anger experience and the process of calming down. Japanese 
Journal of Psychology, 74, 428-436.)

Zeigarnik, B. (1938). On finished and unfinished tasks.

In W. D. Ellis (Ed.), A source book of Gestalt psychology. New York: Harcourt, Brace, \& World. pp. 300-314.
Zilliman, D. (1971). Excitation transfer in communication-mediated aggressive behavior. Journal of Experimental Social Psychology, 7, 419-434.

- 2010.1.14 受稿, 2011.9.6 受理一 